UDC 821.111:811.130.122

DOI https://doi.org/10.32841/2409-1154.2019.43.2.27

\author{
Diadechko A. M., \\ PhD in Philology, \\ Associate Professor at the Foreign Languages Department \\ Sumy State University
}

\title{
R. J. WALLER AND HIS VIEWS ON HUMAN LIFE AND BEING
}

Summary. The literary pieces of Robert James Waller, an American novelist, an essayist, a musician, and a photographer, though very popular in his native country and among English-speaking readers beyond it, have neither been commonly recognized and intensively discussed among Ukrainian linguistic and literary academic circles, nor they have been available for their appreciation to the determined and concerned Ukrainian readers. His novel "The Bridges of Madison County" makes the only exception, probably due to the fact that it was filmed and watched internationally. Ukrainian resources are extremely scarce when presenting any kind of information about R. J. Waller himself and his fiction and non-fiction works. Thus the article aims at throwing light upon R. J. Waller both as a writer and as a person, that is at revealing to what degree the literary works of this careful observer and original thinker manifest and reflect closely his personal views and ideas. Therefore, it seems reasonable to consider Waller's texts from the point of view of at least two philosophical approaches, which are so typical for modern art, literature, psychology, and culture in general, namely existentialism and eco-criticism. The article reveals the ways in which Waller's writings follow and come in accordance with some basic ideas, concepts, and principles of existentialism (human life and being concerned meaningfully, individual freedom and choice-making, taking personal responsibilities, coping with existential crises, etc.) and eco-criticism (building and gaining ecological consciousness, taking personal responsibility for ecosphere) through the analyses of Waller's literary texts as well as his speculations coming from the interviews and other resources concerning his personal life and professional career. Numerous textual abstracts and phrases as well as their philosophical interpretations are given in conformity with these two trends. The primary focus is made on the texts of Waller's collection of essays published in 1994 in his book entitled as "Old Songs in a New Café". Though indirectly, the study reveals and reflects some social concerns of the Americans of the 1980s. and 1990s.

Key words: philosophy, existentialism, existence, eco-criticism, ecological consciousness.

Problem statement. It is evident that Robert James Waller (1939-2016) and his writings deserve closer attention, keener interest and proper appreciation on the part of both domestic scholars and reading community. Only a few of them are in the know that he became a legend in his own time. The story of his popularity began in 1992, when the novel "The Bridges of Madison County" [1] came from an unexpected and unknown author - a Midwest born and bred economics professor named R. J. Waller. He had grown up on a farm in Iowa, received his BA in Business Education at the University of Iowa, and began to develop interests in music and literature. By 1964, he also earned a Master's in Education, then went to Indiana University where he received his $\mathrm{PhD}$ in 1968 , became a professor of economics and business management back at the University of Northern Iowa. He would become the dean of the business school in Cedar Falls until 1985. Being dissatisfied with his career over time, he changed his life crucially and drifted into writing essays, composing songs, taking pictures and later in 1989, he took an unpaid leave of absence for several years [2; 3,].

According to Waller's publisher, with time, unexpectedly, readers' interest became focused on the author's personality rather than on the subjects he touched in his works, essays in particular[4]. They began being concerned about Waller's personal views and senses produced in his pieces the way he saw his life, how he sensed it, and how he managed to put both into words. Undoubtedly, Waller's pieces, especially his essays, gained their readers' appreciation for they notified some philosophical senses.

Thus, the purpose of the article is to investigate to what degree Robert James Waller's personal views, his writings, as well as his doings, conform to basic postulates of some modern philosophical approaches. The object of the study being literary pieces, interviews, and all kinds of publications referring to Waller both as a writer and as a person, the subject of the study is a psychological and philosophical views and considerations presented in the texts related to Waller's personal and professional life and activities. As for methods applied in the study, they include a discourse, logical, structural, and cognitive analysis.

Discussion and results. Presumably, most of Waller's writings as well as his opinions voiced publicly, can be reflected on from the point of view of existentialism to varying degree. Existentialism is known to be a movement in philosophy and literature based on the view that humans define their own meaning in life and try to make rational decisions despite existing in an irrational universe [5]. It focuses on the question of human existence and the feeling that there is no purpose or explanation at the core of existence [6]. Waller himself had never referred to existentialism directly or purposely, when asked about or commenting on his writings. But while reading and speculating upon Waller's pieces, considering his thoughts and reflections, which he makes the subjects of his writings and interviews, we can conclude that he wrote primarily for himself in order to reveal his human self and grasp the way his inner world coexisted with the one around him. Therefore, probably partly, he is inclined to take human life and personality's being proexistentially. Existentialism emphasizes one's individual existence, freedom, and choice. It believes that individuals are entirely free and must take personal responsibility for themselves [7]. Waller definitely manifested the like ideas when drawing his readers into his quest for self-discovery, because he saw the creative process as a personal exercise in self-discovery. "I am discovering as I write, what I really think, what I really believe," he explains in his essay "Getting the Words Rightly Set. This is the magic and the power- 
of creative writing as a means of self-expression." "Your deepest feelings can cause you to shudder a bit... because you didn't know they were there and writing has uncovered them" [8]. For some people this sort of discovery can be startling and troubling, as they are not ready to express what is within them and what they think is only their own. But Waller dares to describe these feelings, and does so with great skill and with the elegance of his language.

For existentialism followers, searching for and finding the way in life (existence) is primarily essential. In his preface to "Old Songs in a New Café" Waller addresses his personal credo to the readers directly and openly: "This is a book about people and animals and things I care about. It's about growing up and showing your stuff, finding love, winning and losing, and getting older. It's about where I began and where I came to at a particular time in my life, as a person and as a writer. And I suppose it's also about where I'm headed. Though I never seem to realize such things at the time. We come, we do, we go, and the doing can be a rather grand voyage if you don't panic and if you believe, as I believe, in magic and imagination and wizards who live along quiet country rivers" [8]. Waller reminds his readers about taking their personal responsibility for whatever they choose or do, though it is never easy. In existentialism individuals act independently and consciously when they try creating their own values and giving a meaning to their life: "At some point, you have to deal with a hard and essential fact: you discover that the things you're good at and the things you love are not necessarily the same" [8, p. 104].

Like most of existentialists, Waller never followed the way that most of people commonly take, never being afraid to look or sound antisocial. He explained his reluctance to attend public events in his own way: "You have fewer people at your funeral, but you get more reading time. $<\ldots>$ There are krakens out there gobbling your life, and it's crucial that they be spotted and nullified" [8, p. 104-105]. In his interview to Dana Kennedy he explains that he respects people who do not like his work because he is a non-skilled amateur.[10] He never really cared what anyone thought of him. Waller' former editor from Iowa State University Press Bill Silag once wrote: "He is a strong guy. He is not always looking around to make sure he is doing the right thing or worrying about offending someone. He gets things done. He moves in straight lines" [10].

When touching the theme of death, Waller, the author of extremely poetic and sentimental prose, often turned into a man of dry figures as an economics professor: "Immortality is a futile search. We come, we do, we go. We all leave a trail. One hopes that the trail is not too damaging" [9]. Such views of his also conform completely to existential view on inevitability of death but, what is really important, is taking one's time: "I propose there is an insidious plot to steal our time in the world we have created, and it's important to get rid of as many encumbrances as possible... The sign my wife posted a long time ago says it rather nicely: "Today I Cherish, Tomorrow I Dust" [8, p. 104]. Taking one's time is the essence of being, it is a talent and a privilege: "An inherent kindness exists in the process of aging. Except for the unforeseen miseries of homicide or wars or sudden catastrophic illness, we are allowed to move along gradually... We graciously are given time to adjust" $[8$, p. 102]. Being on move, always on the way is really important for Waller. He sees his life's end readily and selfconsciously, but before he hopes to take his time and his way: "Like an old rider of the surf, I can already see the next wave coming. It looks fine and fair. It looks worth the effort" [8, p. 109].
Waller's essay "The Turning of Fifty" makes a perfect example of his existential concerns. He starts his story humorously and ironically making a statement:" In my late forties, I came quartering down the years and forgot how old I was" [8, p. 97]. His initial approach to his turning fifty as a mere matter of ciphers happened to differ from what others took it. His friends arranged a small birthday party that fit Waller's character two days before his birthday. He appreciates, that on the day itself no trivial vulgar rituals came: "No "Over-the-Hill Gang." T-shirts were purchased, no champagne was chilled, and bad jokes about getting older were avoided entirely. My wife wrote me a lovely note that said, "I'm short on words, but long on love..." [8, p. 99]. It is Waller's friends and relations who made him think about the significance of the day and here come his concerns which are mostly meaningful in terms of existentialism. With that elegant humor and imagination, he drifts to measuring his personal existence against those of famous historical personalities of the past on the date of his birthday, Galileo Galilei, Thomas Bayes, Socrates, and Alexander the Great among them. Then, turning to allusions, he speaks jokingly but more clearly about his idea of one's searching for and finding his self. He even mentions some world-known existentialists which makes the readers understand his deep personal interest and concern about their core ideas and views: "Ontologists searching for the meaning of existence generally leave me behind in their quest, at least in their writings. I suppose, as with other such matters, it would have helped to have been there, at a Café Flore with Sartre, de Beauvoir, and the rest when they gathered to deal with the foundations of being" [8, p. 100]. Waller metaphorically describes the role of feelings and intuition that existentialisms typically emphasizes: "For me $<\ldots>$ Existence takes on meaning only when you give a meaning by making it meaningful. And how do you make it meaningful?" By listening to those almost-secret voices within you that, at certain critical times, whisper, "This is me" [8, p. 102].

Moments when people start worrying whether their lives still have purpose or meaning, existentialists define as existential crises. Some individuals might even burst into despair caused by their obtrusive negative speculations as for their purpose of life and inevitability of death [7]. In his essay, Waller writes about his particular crisis openly and sincerely: "Around twenty-two, however, I endured what I call 'mortality crisis'. For six months, almost involuntary, I lay in bed at night examining the edges of my psychology, seeking piece with the tenuousness of it all. I lay there in the darkness, thinking and sweating, terrified at the prospect of my own death. That period was excruciating but healthy, I believe, for I determined that time and I should be wary allies, not opponents" [8, p. 106]. In another essay by Waller, he tells about his daughter's entering adulthood and leaving home for University studies. He describes how he is trying to cope with his fatherly crisis. Although he never mentions the term itself, his angst is clearly seen and felt through the text of his narration. Feeling deep responsibility for his daughter's future, Waller drifts to speculations about her existential crisis, which she still has to realize and to manage: "Order has replaced life. I sit quietly there and hear the laughter, the crying, the reverberation of a million phone calls. The angst of her earlyteen existential crisis lingers, drifting in a small cloud near the high ceiling" $[8, p .7]$. Waller understands that he has to reconsider eighteen years of his fatherhood: "Regrets? A few. I wish I had walked in the woods more with her. I wish I had gotten mad less and laughed longer" $[8$, p. 7$]$. 
Existentialism states that human emotions, imagination, and intuition are above all in getting experiences, i.e., existence. Waller puts a similar idea describing Robert Kincaid in "The Bridges of Madison County", who was obviously autobiographical for Waller himself: "Why was not important. That was the way he approached his life. Analysis destroys wholes. Some things, magic things, are meant to stay whole" [1, p. 39]. Waller's style and language is often flooded with emotions: "And men he cried when he talked. He cried big tears, the kind it takes an old man to cry, the kind it takes a saxophone to play" [1, p. 119]. Waller also regrets that rationalism kills romance and imagination: "The market kills more artistic people than anything else. We are giving up free range, getting organized feathering our emotions. Efficiency and effectiveness all those other pieces of intellectual artifice. And with the loss of free range, the cowboy disappears, along with the mountain lion and gray wolf. There's not much room left for travelers" [1, p. 51].

Another modern philosophical approach, which can be also traced in Waller's works, specifically in his essays, is ecocriticism. Conceptually, eco-criticism studies the ways in which literary works are connected with the environment. Literature and culture in general are viewed as authentic constituents of the global environment [11]. Human existence, its meaning, and value must be linked to what is defined today as ecological consciousness. Literature can contribute to the solution of the problem immensely. Eco-critics suggest putting more responsibilities on people in the ecosphere [12].

When Waller made a journey by canoe along the Shell Rock River and then glorified natural beauty of Iowa on the one hand, and showed public negligence about its preservation on the other in his essay, the readers reacted immediately. Waller managed to present his environmental concerns to public in the captivating style and in this way he touched his readers' souls and minds. In the name of progress and development humans abuse, devastate, and kill their surroundings. Waller writes bitterly on it: "More of what? Nothing in particular. Just more. We must have more, always more, for if we stopped, we would have less of that nothing in particular" $[8, \mathrm{p} .116]$.

The image of the river repeatedly appears in his texts and is usually associated with magic and existence: "There, in a quiet, unobtrusive place between two rivers, I found my heroes of a size that suited me" [8]. "... if you believe, as I believe, in the magic and imagination and wizards who live along quiet country rivers" [8]. Even in the short acknowledgments preceding his essays he puts secretively: "And, finally, thanks to the rivers (they know who they are) for being the source of it all" [8].

Unknowingly, when reading Waller's essays, one might not always guess that he is talking about animals and not about human beings. He developed even his own taxonomy of the living world placing humans, animals, rivers, and mountains equally: "Humans have an arrogant manner of ranking life. <.. > I read the philosophers sometimes. <...> But I do not trust their judgements $<\ldots>>$ I prefer to think of civilizations that are, well, just different - separate, but parallel and equal" [8, p. 28].

In his essay "I am Orange Band", Waller makes the main hero of his narration a singing bird, a dusky seaside sparrow, actually the last member of its species, whose extinction the Americans happened to witness. Not many humans noticed that drama of the universe. But Waller did: "But the day Orange Band died there was a faint sound in the universe. Hardly noticeable unless you were expecting it and listening. $<\ldots$.. $>$ If you were listening closely, though, you could hear it $<$... "I am zero" [8, p. 115].

The title "A Canticle for Roadcat", which Waller gave to his another essay, speaks for itself. The lines telling about his good and true friend, especially about Roadcat's getting old and his death, are extremely moving and heartbreaking. Waller describes his cat as a spirited participant of his life and its events and how united the two of them made: "And we came to care, and care deeply, one for the other. He clearly saw, as I eventually did, that power and exploitation were not part of the reflections from other's eyes. We came to the position of trust, and, in his wisdom and elegance, that was all he asked" [8, p. 29].

Conclusions. R. J. Waller's literary pieces are evidently philosophical in their content and style, especially his essays in which he conveys his philosophical senses when focused on such everlasting subjects as family, love, meeting people, building relationships, getting older and going through transitions, nature and environment protection. As they are socially oriented, they reflect the approaches and concerns which were typical and really mattered for the American society of the 1980s and 1990s., and, probably, still matter nowadays. While reading Waller's texts, as well as the articles about him, one can find clear exemplification of some core ideas of such modern philosophical trends as existentialism and eco-criticism.

\section{References:}

1. Waller R. The Bridges of Madison County. New York : Warner Books, Inc., 1992. $192 \mathrm{p}$.

2. Waller R. Just Beyond the Firelight : Stories and Essays. Iowa City : Iowa State University Press, 1988. 184 p.

3. Waller R. One Good Road is Enough. Iowa City : Iowa State University Press, 1988. 284 p.

4. Robert James Waller's Songs/Poetry : An Appreciation. URL: https://webstercity com/event/robert-james-wallers-songs-poetry-anappreciation/.

5. Existentialism. All about Philosophy. URL: https://www. allaboutphilosophy.org/existentialism.htm.

6. The basics of philosophy. Existentialism. URL: https://www. philosophybasics. com/movements_existentialism.html.

7. Stanford Encyclopedia of Philosophy. Existentialism. URL: https:// plato.stanford.edu/entries/existentialism/.

8. Waller R. Old Songs in a New Cafe. New York : Warner Books, Inc., 1994. $172 \mathrm{p}$

9. Hoffman Rich. Journey into the Firelight: The life and death of Robert James Waller. URL: https://overmanwarrior.blog/2017/03/12/journeyinto-the- firelight-the-life-and-death-of-robert-james-waller/.

10. Dana Kennedy, Robert James Waller, a real American cowboy. URL: https://ew.com/article/1994/12/16/robert-james-waller-real-americancowboy/.

11. Khareen B. Culajara, Exploring Representations of Nature in Literature: Ecocritical Themes in the Fiction of Satur Apoyon. URL: https://www.researchgate.net/publication/321369234_Exploring Representations_of_Nature_in_Literature_Ecocritical_Themes_in the Fiction_of_Satur_Apoyon.

12. Ratan Bhattacharjee. An analysis of Eco-criticism and literature with special reference to the works of Hardy and Dickens. URL: https:// www.academia.edu/33313672/An_Analysis_of_Eco-criticism_and_ Literature_with_special_reference_to_the_works_of_Hardy_and_Dickens. 
Дядечко А. Р. Дж. Уоллер і його погляди на людське життя й буття

Анотація. Літературні твори Роберта Джеймса Уоллера, американського романіста, есеїста, музиканта й фотографа, хоча популярні в рідній країні автора й також серед англомовної читацької аудиторії за ії межами, не $\epsilon$ загальновизнаними й не стали предметом широкого обговорення в українських лінгвістичних і літературних академічних колах. Вони також залишаються недоступними для зацікавленої й мотивованої читацької аудиторії в Україні. Винятком є лише роман Р. Дж. Уоллера «Мости округу Медісон», який став всесвітньо відомим після його екранізації. Україномовні джерела надають украй скупу інформацію щодо самого Р. Дж. Уоллера та його літературних творів. Тому мета статті - привернути увагу до Р. Дж. Уоллера як автора, так і особистості, тобто дослідити, наскільки його літературні твори демонструють і віддзеркалюють його особисті погляди й думки. Видається цілком слушним дослідити тексти Уоллера 3 погляду щонайменше двох філософських течій, які набули популярності в сучасному мистецтві, літературі, психології й культурі в цілому, а саме екзистенціалізму та екокритицизму. У статті зроблено спробу виявити, яким чином твори Уоллера відповідають базовим ідеям, концепціям і принципам екзистенціалізму (визначення смислу людського життя та буття, особиста свобода і свобода вибору, особиста відповідальність, подолання екзистенціальної кризи) й екокритицизму (формування й набуття екологічної свідомості, особиста відповідальність за збереження екосфери) шляхом аналізу як текстів творів самого Уоллера, так і його поглядів, висловлених в інтерв'ю, а також в інших джерелах, що містять інформацію про його особисте життя та професійну кар'єру. Численні уривки та фрази 3 текстів i ї філософське тлумачення наведено відповідно до вказаних течій. Найбільшу частину дослідження становить аналіз текстів Уоллера зі збірки есе, опублікованої в 1994 р. під назвою "Old Songs in a New Café". Опосередковано стаття торкається загальних проблем соціальної свідомості американського суспільства 1980-х і 1990-х рр.

Ключові слова: філософія, екзистенціалізм, буття, екокритицизм, екологічна свідомість. 